the evolution of Micraster, so that in successive stages of the Chalk he finds variations in the structure of the tests, variations indeed which "are so marked that one can tell by their aid from what zone a Micraster is derived." As passage-forms and mutations form the bulk of the genus, it is necessary to mass certain obviously allied forms into groups which will admit of the zoological continuity being exemplified and the zonal peculiarities noted. This is the plan adopted by Dr. Rowe, and it certainly appears most philosophical to take a series of specimens rather than an individual as the foundation for a zonal specific type ; and to group rather than to try and separate so many forms. It is satisfactory to learn that the detailed zoological work carried out by Dr. Rowe bears witness to the great value of the palieontological zones which were broadly marked out in the chalk of this country nearly twenty-five years ago by Dr. Charles Barrois.

There is no doubt that the careful collecting of fossils from definite horizons, and from horizons in definite sequence, is of the utmost importance in advancing palieontological knowledge. Such work, as a rule, requires prolonged labour, otherwise the conclusions are worse than useless. Now, by close research, it is possible to trace out the successive modifications that occur in stratigraphic sequence, and this has been attempted with the Graptolites, and with several groups of Mollusca and Brachiopoda, as well as with Echinodermata. Even in so variable a group as the Oysters, it is affirmed by Messrs. R. T. Hill and T. W. Vaughan (Bulletin U.S. Geol. Survey, No. I 5 I) that these organic remains possess very distinct specific characters, have definite geologic horizons and are of the greatest value in stratigraphic work. Their value, moreover, may be not merely scientific, but also of some benefit to humanity. Instances have occurred in Texas where, by the aid of these fossils, brought up from great depths in diamonddrill cores, cities upon the point of abandoning the attempt to procure artesian water have been warranted in drilling a few feet farther, and with success.

Views on the duration of geological time have occupied a considerable amount of letterpress during the past fifty years, and during the past few years the subject has been discussed by Mr. (x. K. Gilbert, Mr. J. (i. Goodchild, Sir A. Geikie, Prof. J. Joly, and Prof. W. J. Sollas.

Mr. Gilbert would look to the influence of precessional changes and to the periodic modification of the climatic conditions of the two hemispheres. Contrasted phases of climate would thus occur every 10,500 years, and such changes should be looked for in the strata. Indications of moist or dry climates, of the increase or decrease of glaciers, and of the local fluctuations of sea-level as affecting the character and extent of strata are the indices to which he would appeal.

Prof. Joly, arguing from the amount of sodium at present contained in the waters of the ocean and the amount annually supplied by rivers, claims that a period of between eighty and ninety millions of years has elapsed since the land first became exposed to denuding ayencies. Sodiurn, as stated by Prof. Joly, is the only dissolved substance of which the ocean has retained substantially the whole anount committed to it by the solvent denudation of geological time.

Prof. Eug. Dubois, dealing with the circulation of carbonate of lime, believes that the real lapse of time since the formation of a solid crust and the appearance of life upon the globe may be more than one thousand million years.

Mr. J. G. Goodchild in 1897 also argued that the more trustworthy data relating to the time of formation of marine strata were furnished by deposits of organicochemical origin. He concluded that over seven hundred NO. I627, vOL. 63] million years would be required since the commencement of the Cambrian period.

Although the conclusions arrived at by investigators are widely at variance, it is not improbable that some trustworthy data may in time be gained by the different methods of research advocated by Gilbert and by Joly. As lately remarked by Sir A. Geikie, progress in geology will be best made by the adoption of more precise methods of research and by a hearty co-operation among geologists in all parts of the world ; and I'rof. Sollas well observed in his address at Bradford that "our science has become evolutional, and in the transformation has grown more comprehensive." The work of the palxontologist must be supported by very detailed local fieldwork, work which at present is very much in its infancy. Such work will help in the grand story of "the science of the earth," a story whose materials can only be gathered together by the patient local toiler; while he or she may well be content to see the results worked up by those who by training and opportunity are able to take a comprehensive view of the earth as a whole.

$$
\text { H. B. W. }
$$

\section{LORD ARMSTRONG, F.R.S.}

THE death of Lord Armstrong on Thursday last, in his ninety-first year, will be regretted in the world of engineering and applied science. To the general public he was best known as a manufacturer of munitions of war, but engineers will remember him more for his developments of hydraulic machinery, and in science his name will be associated with the discussion of the duration of our coal fields, and the development, and discharge phenomena, of statical electricity.

William George Armstrong was born at Newcastleupon-Tyne in $18 \mathrm{ro}$, and educated at a school at Bishop Auckland. He adopted the law as a profession, and became a partner in a firm of solicitors; but a strong bent for scientific pursuits led him to study mechanics with more interest than law and eventually diverted him into another career. Early in life he began investigations of electrical subjects, which resulted in the invention of the hydro-electric machine familiar to all readers of text-books of electricity. The circumstances which suggested this novel electrical machine are well known. The workmen at a colliery near Newcastle had observed that when steam was blowing off from the high-pressure boiler, a smart shock was received if the safety valve was touched, and sparks could be seen. An investigation of the phenomena showed Mr. Armstrong that the boiler was insulated on a dry seating, and the friction of the water particles against the sides of the orifice through which it was escaping caused a development of electricity. On this discovery he based the construction of his hydro-electric machine, which at that time formed the most powerful means of generating frictional electricity. It consisted essentially of an insulated boiler, from which steam at high pressure was allowed to escape through nozzles of peculiar construction. For this he was elected a Fellow of the Royal Society in 1846, while still comparatively a young man.

Another electrical research for which Lord Armstrong will be remembered was concerned with electric movement in air and water, and it culminated in the publication of an elaborate volume on the subject in 1897 . In this work a striking experiment, performed with the hydro-electric machine half a century earlier, was made the starting-point of a valuable research on the nature of electric discharges. Two glasses of distilled water were placed near together, and a thread of cotton, which was coiled up in the one, had its free end placed so as to dip in the other. On negatively electrifying the glass of 
water in which the cc.tton was coiled, and the other glass positively, the thread crept out of its glass into the other, while a stream of water passed in the opposite direction. This and other evidence led Lord Armstrong to conclude that an electric current consists of a negative stream flowing in one direction surrounded by a sheath of positive stream flowing in the opposite direction. The theory presents difficulties which have not been overcome, but neglecting it altogether, the photographs published to illustrate it are the most remarkable examples of electric discharges ever produced.

To Lord Armstrong the world is indebted for the development of the hydraulic machinery which to-day plays so important a part in the business of our docks and large railway stations. He first invented, the hydraulic crane, and, between 1845 and 1850 , the accumulator by which an artificial head of water is substituted for the natural head. By this invention hydraulic machinery was rendered available in almost every situation. Being very convenient where power is required at intervals and for short periods, it has come into extensive use for working cranes and hoists, opening and shutting dock gates, turning capstans, raising lifts, \&c., and in many cases has procured important economies, both as regards time and money, at harbours and railway stations where large amounts of traffic have to be dealt with. In the Navy, again, its applications are almost infinite in number. In awarding the Albert Medal to Lord Armstrong in 1873 , the Society of Arts recognised the benefits which have accrued to manufactures through his development of the hydraulic transmission of power.

For the manufacture of hydraulic machinery the Elswick Engine Works was founded, and there, in 1854 , was constructed the first rifled ordnance gun that bears the name of Armstrong. Its trials were so satisfactory as regards range and accuracy that it was soon adopted by the Government, and Armstrong was appointed engineer of rifled ordnance, being made C.B. and receiving the honour of knighthood. Under his supervision some 3500 of these guns were turned out between 1859 and 1863 , and England became the possessor of the best armament then in existence.

In 1863, Sir William Armstrong resigned his official appointment, and rejoined the Elswick Manufacturing Company, and in the same year he was president of the meeting of the British Association at Newcastle-uponTyne. In that capacity he drew attention to the gradual lessening of our supply of coal, and the prospects of exhaustion of our coalfields. The discussion suggested by this address led to the appointment of a Royal Commission to inquire into all the circumstances connected with the national coal supply, and he was nominated a member of it. The better utilisation of natural forces was a subject to which he again called attention in his presidential address to the mechanical science section of the Association at York in $188 \mathrm{I}$, when he commented upon the wastefulness of the steam engine, and discussed the question whether its difficulties might be avoided by resorting to electrical methods of obtaining energy.

Lord Armstrong received many honours. Cambridge made him a LL.D. in 1862 and Oxford a D.C.L. in 1870. He was president of the Institution of Civil Engineers in 1882 , and he more than once served the same office in the Institution of Mechanical Engineers. An original member of the Iron and Steel Institute, he was in I8gI awarded the Bessemer Medal by that body, and the large number of foreign decorations which were bestowed upon him attested the reputation which his work won for him abroad. His presidency of the Newcastle Literary and Philosophical Society was the occasion for several noteworthy addresses, and he wrote a number of articles, pamphlets and short treatises on scientific subjects. His public spirit and philanthropy are justly appreciated in
Newcastle. A lecture hall for the Literary and Philosophical Society, an operating theatre for the Infirmary, thousands of pounds towards the restoration of a fine old steeple, other thousands to the Children's Hospital, three-quarters of a $20,000 l$. bridge across Benton Valley, $10,000 l$. to the Natural History Museum, a Mechanics' Institute, and schools for the Elswick men, a banqueting hall, public parks-these were among his gifts to the city.

For these works, as for his contributions to the progress of science and industry, his name stands high among the great men of the century.

\section{WILLIAM POLE, F.R.S.}

M R. WILLIA.M POLE, F.R.S., whose death occurred on December 30, at the age of eighty-six, was distinguished both as an engineer and as a musician. He was born in Birmingham in 1814 , and, after following the profession of engineering for some years, was appointed professor of civil engineering in Elphinstone College, Bombay. In 1847 he returned to London, devoting his chief attention to the mechanical branch of his profession, and soon became a recognised authority on engineering matters Between 1859 and 1867 he was professor of civil engineering at University College, London, and lecturer at the Royal Engineer Establishment, Chatham. He served on the Council of the Institution of Civil Engineers from $187 \mathrm{I}$ to 1875 , in which year he was appointed honorary secretary.

Mr. Pole's services to the Government in carrying out scientific work of various kinds were very important. In $186 \mathrm{I}-1864$ he was a member of the committee on iron armour, and from that year till 188 ; he was almost constantly employed by the Government in one of its departments, bringing the knowledge of an expert to bear on questions differing so widely as the comparative merits of the Whitworth and Armstrong systems of artillery and the gas and water arrangements of the metropolis. He acted as secretary to four Government commissions of inquiry-namely, from $186 ;$ to 1867 to the Royal Commission on Railways, from 1867 to 1869 to the Royal Commission on Water Supply, from 1882 to 1884 to the Royal Commission appointed to inquire into the pollution of the Thames, and in 1885 to a conimittee on the science museums at South Kensington. From 1871 to 1883 he was consulting engineer for the Imperial railways of Japan, and on his retirement the Mikado decorated him with the Imperial Order of the Rising Sun.

In June, I86I, Mr. Pole was elected a Fellow of the Royal Society of London, and was vice-president in 1876 and 1889 . He was elected into the Royal Society of Edinburgh in 1877 , and into the Athenæum Club as a man of "distinguished eminence in science," in 1864. $\mathrm{He}$ published in 1844 a quarto treatise on the steam engine; in 1848 a translation of a German work on the same subject ; in I 864 and 1870 "Scientific Chapters in the Lives of Robert Stephenson and I. K. Brunel"; in 1872 a treatise on iron; in 1877 he wrote the life of Sir William Fairbairn, and in 1888 that of Sir William Siemens. He was also the author of a well-known scientific work on the game of whist, and contributed a number of papers to scientific journals and periodical literature.

Mr. Pole was skilled both in the theory and practice of music. He took the Oxford degree of Bachelor in 1860 , and in 1867 that of Doctor of Music. He also held for some years the office of examiner in music at the University of London. He was the author of "The Philosophy of Music," "The Story of Mozart's Requiem," and other compositions.

No. 1627 , voL 63] 